\title{
ASEAN'S CENTRALITY IN THE INDO-PACIFIC AND THE SOUTH CHINA SEA DISPUTE
}

\author{
Sushri Sangita Barik ${ }^{1}$ \\ ${ }^{1}$ PG Scholar-Political Science, Department of Politics and International Studies, Pondicherry \\ University
}

\author{
Ayadoure S Stalin ${ }^{2}$ \\ ${ }^{2}$ PG Scholar-International Studies, Department of Politics and International Studies, \\ Pondicherry University
}

Article DOI: https://doi.org/10.36713/epra5633

\begin{abstract}
The South China Sea is the contested region between several ASEAN member nations and China. The rise of China along with its offensive Realpolitik policy has offended the sovereignty of many territorial nations in the South China Sea. In this article, the researchers would schematically analyze through the documentary analysis on the ASEAN's Centrality. Based on the epistemological and ontological inference, the researchers would argue that the ASEAN's centrality is based on the neo-liberal dilemma of reciprocity and thus neglecting the Statism in the South China Sea.
\end{abstract}

KEYWORDS: ASEAN, China, Indo-Pacific, Reciprocity, and the South China Sea Dispute.

\section{INTRODUCTION}

The emergence of China as the largest economy posits it to be the USA's systemic rival in the IndoPacific. China's assertive and unilateral policy of claiming legitimacy by declaring the South China Sea as its undisputable sovereign area by propounding the Nine-Dash Line that led to unrest among many littoral island countries. The result of this course was the challenge to 'Freedom of Navigation' in this region which in turn affected the major maritime powers interest like the US, Japan, etc. India as an emerging superpower viewed by the USA as a balancing state to China, the latter is continuously asserting its claim by citing the historical reason, flexing its muscles by initiating many unilateral measures like constructing artificial islands and military drills, for instance, the Spratly Island Case. However, the ASEAN Nations who are the vital actors in this dispute, in their 2019 July communique titled ASEAN Outlook on the IndoPacific, believes that the multilateral engagement with China and the USA is the inclusive option to diffuse the tension in the Indo-Pacific in general and the South China Sea Dispute in particular also underscored that such engagements are the means to enhance trust in the region which will eventually create Win-Win situation (ASEAN, 2019). In this context, this article intends to analyze the ASEAN's centrality in the Indo-Pacific Region and their dilemmas on the South China Sea dispute. This paper hypothesizes that ASEAN's centrality is based on ASEAN's expectation that China would reciprocate thus reduces conflict region.

The South China Sea is highly strategic relevant due to the convergence of the resources that favours the blue economy, energy security, food security, etc. China with vast huge land and populations needs more resources to feeds its people and they view the South China Sea being a less exploited region as a potential destination. Also, China views the South China Sea's geographical proximity to Malacca Strait, Sunda Strait, Lombok Strait, and Luzon Strait as ideal statecraft for its Two Ocean Strategy. In that note to explicate the maritime superhighway relevance of these straits in the South China Sea, Zenel Garcia in her book titled China's Military Modernization, Japan's Normalization, and the South China Sea 


\section{EPRA International Journal of Research and Development (IJRD) \\ Volume: 5 | Issue: 11 | November 2020 \\ - Peer Reviewed Journal}

Territorial Disputes commented that the South China Sea is one of the main arteries for global shipping, $50 \%$ of the world's merchant fleet tonnage crosses through the Malacca, Sunda, and Lombok Straits, with the majority continuing into the South China Sea (Garcia, 2019). A critical study moots the following question to critically examine why do the ASEAN expecting reciprocity from the South China Sea?

\section{ASEAN'S CENTRALITY: CRITICAL EXAMINATION}

The USA views China as a Systemic rival and on the rationality of its Indo-Pacific Policy that the systematic development of China's military capability will endanger the USA's military capabilities in the East Asian Region and eventually lead to denial of the USA's access in the Western Pacific (Cáceres, 2014). The USA also considers that China is a parochial power that is now intimidating several nations in the Indo-Pacific Nation to encroach territory. Despite considering China as a parochial power, the USA, in Free and Open Indo-Pacific Charter, underscored the narrative that it excludes no nation or intends the Indo-Pacific Nations to choose either one country as well, rather what it professes are the following four tenets, that are: Firstly, respect for Sovereignty and independence of all nations; Secondly, peaceful resolution of the disputes; Thirdly, free fair, and reciprocal trade based on open investment, transparent agreements, and connectivity; and Fourthly, adherence to international law, including freedom of navigation and overflight (U.S. Department of the State, 2019). It is very clearly absolved that the USA keeping its Indo-Pacific Strategy vision and it is not particularly targeted against any nation per se China but the contradiction is how China became a systemic contender to the USA?

The USA's basic tenets in the Indo-Pacific are viewed by China as they are directed against it like: the 'respect for Sovereignty' as envisaged in the charter has been presumed by China that it implicates China's aggression in the South China Sea. This presumption followed by China's aggressive patrolling in the South China Sea and counterclaiming the rights of passage viewed by the USA that China is not adhering to the international laws like the UNCLOS. What is the key point of difference between the USA and China's view on Indo-Pacific is: USA views the ASEAN as one regional entity but China does not view the ASEAN as one entity rather prefers each country's perspective than one common code. This, China's differing view had prolonged the efforts to attain the South China Sea's Common Code of Conduct. A sizeable number of scholars advocates that ASEAN's centrality is primarily due to the principle of reciprocity, ASEAN is advocating the Institutionalist idea of Keohane by why proffering centrality. ASEAN's Centrality had negated explicitly the case of the zero-sum game to rule out the case of prisoner's dilemma to China.

Expecting reciprocity from China for co-operation, the ASEAN nations have explicitly asserted their rational egoism by making other Indo-Pacific stakeholders acceding the ASEAN's Centrality in the Indo-Pacific thus complicating the chances of China's demand for an individual-based common code. In this pursuit, ASEAN's victory in the multilateral arbitration again posits the rational egoism that they will cause the advocacy for a rules-based IndoPacific which would limit the cause of the USA and the other regional Indo-Pacific nations in the South China Sea. The tangible inference is that ASEA's reciprocal and rational egoism would cause China to asserts its neo-realist policy to cause status-revision in the South China Sea and would seek bandwagoning in the pursuit of China's interest. In other words, ASEAN's centrality and zero-sum game and the USA's departure from the Trans-Pacific Cooperation have been the catalyst to the process of China's dominance in the Indo-Pacific.

\section{CONCLUDING OBSERVATION}

Nevertheless, multilateral engagement is mandatory in a multi-folded dispute like the South China Sea and it is imperative to have all track level dialogues to diffuse the fevers at the South China Sea. At the same time, the multilateral engagements shall not be 'China minus' and the ASEAN's centrality in the Indo-Pacific explicates the imperative of the common code in the South China Sea. The recent US Presidential election and the victory of His Excellency Joe Biden will cause the ex-post-facto dated 2016. In that direction, recently ASEAN Nations had strongly condemned the Chinese aggression in the South China Sea during the pandemic crisis and emphasized that China is bound by UNCLOS too. The ASEAN's Communique had underscored the importance of their priorities that is cooperation in maritime, connectivity, sustainable development, and economic integration. This communique indicates that ASEAN has corrected its 'ASEAN Way' of expecting reciprocity for cooperation

\section{BIBLIOGRAPHY}

1. ASEAN. (2019, June 23). ASEAN Outlook on the Indo-Pacific. Retrieved from ASEAN: https://asean.org/asean-outlook-indo-pacific/

2. Cáceres, S. B. (2014). China's Strategic Interests in the South China Sea: Power and resources. New York, USA: Routledge.

3. Garcia, Z. (2019). China's military modernization, Japan's normalization, and the 
south china sea territorial dispute. New York: Palgrave Macmillan.

4. Keohane, R. O., \& Martin, L. L. (1995). The Promise of Institutionalist Theory. International Security, 39-51.

5. ORF. (2020, March 6). Act east to act IndoPacific: India's expanding neighbourhood. Retrieved from Observer Research Foundation: https://www.orfonline.org/research/act-east-toact-indo-pacific-indias-expandingneighbourhood-61985/

6. Suzuki, S. (2010). The myth and reality of China's 'soft power'. In I. Parmar, \& M. Cox (Eds.), Soft Power and US Foreign Policy: Theoretical, Historical and Contemporary Perspectives (Routledge Studies in US Foreign Policy) (pp. 199-214). London: Routledge.

7. Thakkar, M. (2020, February 20). South China Sea of brewing troubles and its implications for India. Retrieved from Modern Diplomacy: https://moderndiplomacy.eu/2020/02/18/southchina-sea-of-brewing-troubles-and-itsimplications-for-indial

8. The Economic Times. (2019, June 1). Act East to act Indo-Pacific: Agenda for the new government. Retrieved from The Economic Times:

https://economictimes.indiatimes.com/news/defen celact-east-to-act-indo-pacific-agenda-for-thenew-

government/articleshow/69591279.cms?from $=m$ $d r$

9. U.S. Department of the State. (2019, November 4). A Free and Open Indo-Pacific: Advancing a Shared Vision. U.S. Department of the State. Retrieved from https://www.state.gov/: https://www.state.gov/wp-

content/uploads/2019/11/Free-and-Open-IndoPacific-4Nov2019.pdf.

10. Yao, Y. (2015). Diplomacy, China's Approach to Economics. In G. J. Ikenberry, W. Jisi, \& Z. Feng (Eds.), America, China, and the Struggle for World Order: Ideas, Traditions, Historical Legacies, and Global Visions (pp. 161-188). Palgrave Macmillan US: Palgrave Macmillan US. 